\title{
Pawet Dybel
}

\section{Samopoznanie czy farmakoterapia? \\ Filozoficzne implikacje sporu wokół soma i psyche w ujęciu psychoterapii przez Romana Markuszewicza \\ Self-cognition or pharmacotherapy? \\ Philosophical implications of the dispute around soma and psyche in Roman Markuszewicz's concept of psychotherapy}

Stowo jest wielkim mocarzem, który za pomoca bardzo matego i ukrytego organu (języka) wywotuje rzeczy na miare boska. Zdolne jest bowiem i strach uśmierzyć, $i$ troskę odsunać, radość wzbudzić i wspótczucie pomnozyć. [...] Samo zaś stowo posiada taka moc oddziatywania na dyspozycję psychiczna, jak leki na kondycję fizyczna cztowieka. Jak niektóre leki uwalniajac $z$ organizmu pewne ciecze ustrojowe raz ktada kres chorobie, a innym razem życiu, tak $i$ stowa: jedne smuca stuchaczy, drugie ciesza, jedne przerazaja, drugie dodaja odwagi, jeszcze inne przy udziale jakiejś złej namowy pętaja i mamia duszę.

Gorgiasz, Pochwata Heleny, par. 8 i $14^{1}$

To oto uczynitem, twierdzi moja pamięć; niemożliwe jest, abym to uczynit, twierdzi moja duma - i pamięć ustępuje.

Friedrich Nietzsche, Poza dobrem i ztem, par. $68^{2}$

1 Gorgiasz, Pochwata Heleny, przeł. K. Tuszyńska, „Przegląd Humanistyczny" 1984, t. 28, nr 3, s. 110 i 113.

${ }_{2}$ Cytowane za R. Markuszewicz, Psychoanaliza i jej znaczenie lecznicze, „Warszawski Kalendarz Lekarski” 1926, s. 272. 


\section{Streszczenie}

Kwestia ujęcia relacji między ludzkim ciałem, jego fizjologicznym podłożem, a sferą życia psychicznego człowieka od stuleci była przedmiotem zażartych dysput filozoficznych. We współczesnej psychiatrii i psychoterapii przybrała ona postać sporu wokół tego, w jakim stopniu sfera ludzkiego życia psychicznego jest autonomiczna, w jakim zaś jest zdeterminowana przez fizjologiczne podłoże ludzkiego ciała. Spór ten ma nie tylko ściśle antropologiczny wymiar, ale dotyczy zarazem kwestii obrania przez psychiatrę odpowiedniej metody terapii pacjenta. W artykule przedstawiam stanowisko, jakie zajął w tej kwestii Roman Markuszewicz, wybitny polski psychiatra o orientacji psychoanalitycznej, działający w okresie międzywojnia. Podkreślam zarówno jego krytycyzm wobec tradycyjnych form terapii „przez wiarę", jak i wobec orientacji deterministycznej, stawiającej na psychochirurgię i farmakoterapię. W artykule przytaczam jego podstawowe zarzuty przeciwko tym obu formom terapii oraz argumenty na rzecz efektywności Freudowskiego modelu terapii, opartego na dialogu z pacjentem i dążeniu do zmiany jego samowiedzy.

Słowa kluczowe: psychoanaliza, psychiatria, psychoterapia, hermeneutyka, rozmowa, farmakologia, psychochirurgia, psychodynamika

\section{Summary}

The problem of how to apprehend the relationship between the human body, its physiological basis and human mental life has been the object of fiery philosophical debate for centuries. In modern psychiatry and psychotherapy, it revolves around the question of the extent to which human mental life is autonomous or is determined by the physiological processes of the human body. This dispute is not confined to the strictly anthropological dimension; it concerns also the question of the psychiatrist's choice of an appropriate method of therapy for a patient. In this article, I present the standpoint adopted on this issue by Roman Markuszewicz, a prominent psychoanalytically-oriented Polish psychiatrist in the period between the two world wars. He was critical both of traditional forms of therapy 'through faith' and also of modern forms of therapy based on psychosurgery and pharmacotherapy. I discuss his main objections to these two different forms of therapy and his arguments for the effectiveness of a Freudian model of therapy based on dialogue with the patient and on an attempt to transform his self-understanding.

Keywords: psychoanalysis, psychiatry, psychotherapy, hermeneutics, dialogue, pharmacology, psychosurgery, psychodynamics 
Niektóre spory naukowe, mimo że zmienia się zasadniczo postać dyscyplin, w obrębie których się one toczą, trwają przez stulecia. A nawet tysiąclecia, jeśli sięgniemy do czasów starożytnej Grecji. Trwałość tych sporów wiąże się z tym, że mają one zazwyczaj filozoficzny wymiar. Dotyczą nie tylko kwestii szczegółowych, związanych z partykularną problematyką danej dyscypliny, ale zawierają pewien aspekt ogólny. Taką postać mają spory we współczesnej psychiatrii i psychoterapii na temat tego, jakie podejście należy uznać za najbardziej owocne w leczeniu zaburzeń psychicznych. Czy to, które koncentruje się na ciele człowieka i polega na oddziaływaniu nań różnymi lekami? Czy też to, które nacisk kładzie na uzdrowienie jego duszy na drodze prowadzenia z nim rozmowy? Te dwa podejścia odsyłają do pytania o to, w jakiej relacji pozostają w człowieku psyche i soma, a jest to pytanie, które pojawiło się już u początków filozofii. Dzisiaj pierwsze stanowisko zajmują we wspomnianych dyscyplinach przedstawiciele nurtów, nazwijmy je umownie, „deterministycznych”, drugie zaś nurtów „humanistycznych”.

Ci pierwsi utrzymują, że najbardziej skuteczną formą terapii jest dzisiaj podejście, w którym korzysta się ze zdobyczy psychologii zorientowanej doświadczalnie. Podejście to opiera się na założeniu, że oddziałując za pomocą odpowiednich leków na fizjologię ciała pacjenta można osłabić lub całkowicie

${ }^{3}$ Wprowadzone tutaj przeze mnie rozróżnienie na nurty „deterministyczne” i „humanistyczne” we współczesnej psychiatrii z pewnością nie oddaje wszystkich panujących tu podziałów i różnic. Istnieje na przykład wiele nurtów, których przedstawiciele starają się na różne sposoby łączyć elementy jednego i drugiego podejścia. Ale jest to najbardziej fundamentalny podział w tej dziedzinie, zaś wszelkie stanowiska pośrednie sytuują się w jego obrębie. 
zneutralizować szereg patologicznych przejawów jego życia psychicznego, również tych o charakterze schizofrenicznym. W niektórych przypadkach równie skuteczne mogą się okazać zabiegi chirurgiczne, np. usunięcie chorych fragmentów mózgu pacjenta. Zakłada się tutaj zatem, że w terapii należy wyjść od odpowiedniego oddziaływania na soma pacjenta, co spowoduje oczekiwane efekty w obrębie jego psyche.

Drudzy wychodzą natomiast z założenia, że w terapii należy wyjść od oddziaływania na psyche pacjenta. W jej trakcie należy zatem doprowadzić do przeobrażenia samowiedzy pacjenta, jego dotychczasowego stosunku do siebie i do innych. To zaś może się dokonać dopiero wtedy, gdy z pacjentem się rozmawia lub zaleca mu się np. szereg ćwiczeń natury fizycznej i duchowej (np. joga i inne techniki fizyczno-duchowe lub czysto duchowe), które pozwalają mu rozluźnić się psychicznie, uzyskać spokój wewnętrzny, zdobyć panowanie nad sobą. Przy czym naturalnie sama rozmowa, w zależności od metodyki jej prowadzenia ustalonej w ramach danej szkoły czy nurtu, może przebiegać różnie. W wyniku tego nowy stosunek pacjenta do siebie i innych z najbliższego otoczenia pozwala mu pozbyć się symptomów (względnie je w jakimś stopniu zneutralizować) i lepiej odnaleźć się w rzeczywistości społecznej.

Te dwa stanowiska są trudne do pogodzenia, gdyż reprezentujące je strony wychodzą od wykluczajacych się nawzajem założeń dotyczących relacji między fizjologicznym podłożem ludzkiego ciała a sferą jego życia psychicznego. Na jednym biegunie znajdują się więc psychiatrzy, którzy uważają, że w związku ze zdeterminowaniem wszystkich procesów psychicznych człowieka przez ich fizjologiczne podłoże należy przede wszystkim badać te zależności i w oparciu o te badania obmyślać odpowiednie rodzaje leków. W zależności od tego, jakie składniki procesów fizjologicznych uzna się za powodujące danego typu zaburzenia u pacjenta, podać mu należy leki o odpowiednim składzie chemicznym, które będą neutralizować negatywny wpływ tych składników. 
Pogląd taki wypowiedział po raz pierwszy dobitnie Emil Kraepelin u progu XX wieku, dając początek nurtowi farmakoterapeutycznemu w psychiatrii, w którym źródeł wszelkich zaburzeń psychicznych upatruje się w fizjologii ludzkiego cia$\mathrm{la}^{4}$. Zdaniem przedstawicieli tego nurtu najskuteczniejszą formą terapii jest farmakoterapia, opierająca się na osiągnięciach farmakologii. Inną dopuszczaną przez nich formą jest psychochirurgia, czyli zabiegi operacyjne usuwające chore organy lub ich fragmenty, będące źródłem zaburzeń ${ }^{5}$.

Formułując ten pogląd, Kraepelin był kontynuatorem podejścia „somatyków” (die Somatiker) w XIX-wiecznej tradycji niemieckiej psychiatrii, którzy wychodzili z założenia, że, jak pisze Mira Marcinów: „właściwym dla medycyny modelem choroby psychicznej powinno być ujmowanie jej z perspektywy

${ }^{4}$ E. Shorter, A History of Psychiatry. From the Era of the Asylum to the Era of Prozac, John Wiley \& Sons, New York 1997, s. 101.

5 Tak utrzymuje np. Włodzisław Duch z UMK w Toruniu. Jakkolwiek jest on fizykiem i kognitywistą, a nie psychiatrą czy psychoterapeutą, to w jego argumentacji w uproszczonej postaci rozpoznajemy schemat myślenia, jaki tkwi u podstaw deterministycznie zorientowanych teorii psychoterapii. W wykładzie zatytułowanym Neurobiological Foundations of Ethics and Law, otwierającym konferencję Ethics in Science and Life pod auspicjami Fundacji Alexandra von Humboldta w Toruniu w maju 2015 roku, twierdził on, że każdej postaci zaburzenia psychicznego odpowiada jakiś rodzaj patologii mózgu. Dlatego terapia wszelkich zaburzeń psychicznych przedstawia się dzisiaj bardzo klarownie i prosto w swych metodycznych założeniach. Najpierw identyfikujemy w mózgu pacjenta miejsce, które jest źródłem choroby, a potem usuwamy tę chorobę poprzez odpowiedni zabieg chirurgiczny. Względnie podajemy leki, jeśli tylko sa one w stanie usunaćc tę patologię (abstrakt wykładu Ducha znajduje się w materiałach tej konferencji udostępnionych uczestnikom). U podstaw wywodu Ducha tkwi założenie, że cała sfera życia psychicznego człowieka jest zdeterminowana przez procesy fizjologiczne zachodzące $w$ jego ciele. Dlatego jedyna skuteczna forma terapii to oddziaływanie na te procesy poprzez odpowiednie zabiegi chirurgiczne i leki. Naturalnie pytaniem jest, czy Duch nie ujął tu w bardzo uproszczony sposób złożonej problematyki terapii ludzkiej „duszy”. Czy rzeczywiście o wszystkim decyduje tutaj fizjologia? 
somatycznej - to znaczy jako zaburzenia uwarunkowanego wyłącznie zmianami w ciele"6.

Najwybitniejszymi przedstawicielami „somatyków” byli w XIX wieku w Niemczech Wilhelm Griesinger, neurolog i psychiatra, oraz Maximilian Jacobi, nieprzyznający psychiatrii autonomii jako nauce.

$\mathrm{Na}$ drugim biegunie znajdowali się psychiatrzy i psychoterapeuci, których nazywano „psychikami” (die Psychiker). Odwoływali się oni do tradycji niemieckiego romantyzmu i animizmu, upatrując w chorobach psychicznych zakłóceń aktywności duszy. Na ich czele stał Christian August Heinroth, który uważał, że obłęd wynika z niewłaściwego użycia władz umysłowych lub złych zachowań, a nie z zaburzeń funkcjonowania ciała ${ }^{7}$.

W XX wieku kontynuatorami tego podejścia byli przedstawiciele wspomnianych nurtów „humanistycznych” w psychiatrii i psychoterapii. U podstaw ich podejścia do chorób psychicznych tkwi założenie, że postać ludzkiego życia psychicznego i jego „treść” jest autonomiczna w stosunku do fizjologicznego podłoża. Jakkolwiek owo podłoże może niekiedy, np. kiedy mózg pacjenta uległ deformacjom z przyczyn dziedzicznych lub po wypadku, determinować w jakimś stopniu jego przeżycia psychiczne, to w większości przypadków owe przeżycia nie są zwykłą funkcją przebiegających w tym mózgu procesów fizjologicznych. Efektywność leczenia lekami i za pomocą chirurgicznych zabiegów ma granice, których psychiatra i psychoterapeuta winien być świadom. Więcej, farmakoterapia może prowadzić do trwałego uzależnienia pacjenta od podawanych mu leków i w konsekwencji do beznadziejnego zapętle-

${ }^{6}$ Fragment pochodzi z niepublikowanej rozprawy doktorskiej Miry Marcinów, Psychologiczna charakterystyka chorób umystowych w XIX-wiecznej psychiatrii polskiej, Uniwersytet Jagielloński, Kraków 2014, s. 218.

7 Ten spór niemieckich „somatyków” z „psychikami” obszernie omawia Mira Marcinów we wspomnianej rozprawie doktorskiej. 
nia się terapii. Natomiast psychochirurgia często prowadzi do fatalnych rezultatów, nie poprawiając w niczym kondycji psychicznej pacjenta.

Psychiatra i psychoterapeuta winien skoncentrować się na rozpoznaniu $\mathrm{w}$ trakcie rozmowy z pacjentem specyfiki jego osobowości, jego wyobrażeń o sobie i o innych oraz jego stosunku do świata i zgodnie z tym rozpoznaniem zalecić i zastosować odpowiedni model psychoterapii. Ma on więc wniknąć w to, jaki psychologiczny typ osobowości reprezentuje pacjent, w charakter jego reakcji emocjonalnych, sposób jego myślenia, no i przede wszystkim w naturę jego zaburzeń psychicznych (np. czy mają one charakter neurotyczny, czy psychotyczny). Nie bez znaczenia jest tu również zdobycie wiedzy na temat społecznego otoczenia pacjenta, pewnych szczegółów z jego biografii, typu wychowania, jakie otrzymał, jego poglądu na świat, wyznawanych wartości, religii itd.

Wszystkich tych czynników nie można traktować jako funkcji procesów fizjologicznych zachodzących w ciele pacjenta. Jakkolwiek w niektórych drastycznych przypadkach (głębokie stany depresyjne, ciężka schizofrenia, mania samobójcza itd.) psychoterapeuta zmuszony jest przepisać pacjentowi odpowiednie leki, to punkt ciężkości spoczywa na doprowadzeniu $\mathrm{w}$ procesie terapii do zasadniczej zmiany w stosunku pacjenta do siebie i do otoczenia, pobudzenia w nim władzy krytycznej refleksji itd. Słowem, pacjent ma uzyskać tu nowy rodzaj „samopoznania”, gdyż tylko na tej drodze może uwolnić się od różnego typu blokad wewnętrznych, nadpobudliwości, symptomów paraliżujących jego obcowanie z innymi, względnie zneutralizować ich szczególnie ostrą postać.

W tego typu terapii kluczowa rolę odgrywa formuła Talesa, a później Sokratesa: „Poznaj samego siebie!”, która w ich filozofii miała zarazem postać przesłania etycznego. Tkwi ona u podstaw wszelkiego typu „humanistycznych” form psychoterapii, niezależnie od tego, na jakich założeniach się opierają i co konkretnie rozumieją przez pojęcie samopoznania pacjen- 
ta. Na czoło wysuwają się tu takie nurty jak terapia Gestalt, nastawiona na doprowadzenie pacjenta do rozpoznawania własnych uczuć i ich integrowania (Fritz Perls), psychoterapia Carla Rogersa, nastawiona na wspieranie pacjenta w rozumieniu siebie i samoakceptacji, różne typy terapii humanistyczno-egzystencjalnej (Viktor Frankl, Ronald Laing, Irvin D. Yalom), szwajcarska Daseinsanalyse, inspirująca się psychoanalizą i takimi nurtami filozoficznymi jak egzystencjalizm, fenomenologia, hermeneutyka (Ludwig Binswanger, Medard Boss).

Do „humanistycznych” form psychoterapii zaliczyć należy też różne szkoły i nurty w ramach współczesnej psychoanalizy (freudowska, jungowska, kleinowska, lacanowska i inne) oraz inspirujące się ich dorobkiem współczesne koncepcje terapii psychodynamicznej. Wprawdzie założenia wymienionych powyżej nurtów w psychiatrii i psychoterapii często formułowane były w radykalnej opozycji do psychoanalizy, to w różnych dzisiejszych odmianach tej ostatniej samopoznanie pacjenta w procesie terapii również odgrywa kluczową rolę. Różnica polega na odmiennych założeniach antropologicznych (w psychoanalizie, w odróżnieniu do teorii Gestalt czy psychoterapii Rogersa, w ukształtowaniu samowiedzy pacjenta nacisk kładzie się na traumatyczne doświadczenia $\mathrm{z}$ dzieciństwa, które zostały wyparte w nieświadome, a nie na teraźniejszość) i wynikającym stąd odmiennym rozumieniem metody, jaką ma się posłużyć psychoterapeuta, aby doprowadzić do przeobrażenia samowiedzy pacjenta.

Sokrates postulat samopoznania pojmował jako akt świadomości o charakterze intelektualnym, w którym jednostka na drodze wymiany argumentów z partnerem rozmowy zbliża się do uchwycenia istotnego znaczenia jakiegoś pojęcia („sprawiedliwości”, „dobra” itd.). Nieodłącznym elementem tego procesu było zarazem poznanie jakiejś prawdy o sobie. Na tym zasadzać miał się według mędrca z Aten wyróżniony status filozoficznego poznania, w którym uzyskanie pełniejszego i bardziej wielostronnego wglądu w naturę danego pojęcia wiązało 
się ściśle z porzuceniem przez każdego z rozmówców naiwnej postawy tego, kto „wie wszystko”, na rzecz postawy pytającego, który „nie wie nic”.

Ale dialektyka, stosowana przez Sokratesa i rozwinięta później przez Platona, nastawiona była nie tylko na zmianę poglądów rozmówcy w danej kwestii poruszanej w rozmowie. Dotyczyła ona w równej mierze - na co wskazuje Dariusz Olesiński - jego postawy życiowej, „zwłaszcza w aspekcie wzajemnej zgodności słów i czynów. Znajduje to swoje potwierdzenie w Platońskim przekazie, że za naczelny cel i przesłanie Sokratejskiej metody filozoficznej należy uznać poddawanie próbie życia człowieka, które jest wyrazem troszczenia się o jego duszę"8.

Te dwa aspekty, życiowy i poznawczo-filozoficzny, były zatem ściśle ze sobą powiązane. Zmieniały się nie tylko poglądy rozmówcy na temat rozpatrywanego wspólnie z Sokratesem znaczenia pewnych pojęć, ale w równej mierze jego podejście do własnego życia. Tym samym zaś jego stosunek do siebie i do innych. Dlatego w zdobytej przez niego nowej wiedzy na temat tego, jak należy rozumieć roztrząsane w filozoficznej rozmowie pojęcia, w jego zbliżaniu się do prawdy o nich zawarty był pierwiastek terapeutyczny. Jednostka nie tylko dystansowała się od własnych wyjściowych mniemań, gdyż w trakcie rozmowy zaczynała zdawać sobie sprawę z tego, że były one albo fałszywe, albo w zbyt uproszczony sposób ujmowały znaczenie tych pojęć. W rezultacie, zamiast pozostawać w złudnym przekonaniu o słuszności tych mniemań, przyjmowała postawę pytająco-krytyczną, uporczywie zapytując o rzecz. Obierając tę pytająca postawę, jednostka zyskiwała rodzaj niezbędnej busoli, która wskazywała jej, jak ma postępować w poszukiwaniu

8 D. Olesiński, Elenktyka jako therapeia $w$ świetle Platońskiego Eutyfrona, w: Therapeia, askesis, meditatio. Praktyczny wymiar filozofii w starożytności i średniowieczu, red. K. Łapiński, R. Pawlik, R. Tichy, Wydział Filozofii i Socjologii Uniwersytetu Warszawskiego, Warszawa 2017, s. 49. 
prawdy. Uzyskiwała więc swego rodzaju spokój ducha, który pozwalał jej odnajdywać się w trudnych dla niej sytuacjach życiowych. Ten głęboki wewnętrzny spokój i niezłomność pytającego wymownie oddaje obraz Sokratesa przed sądem, przedstawiony w rozprawie Platona9.

\section{2.}

W sporach wokół sposobu ujęcia odniesienia sfery soma do psyche oraz wynikających stąd metodycznych konsekwencji dla prowadzenia terapii, które się toczą we współczesnej psychiatrii i psychoterapii, nietrudno rozpoznać jedną z wersji znanego od czasów myśli greckiej filozoficznego sporu na temat sposobu, w jaki ciało człowieka odnosi się do jego duszy. Spór ten nabrał szczególnej ostrości w XIX wieku wraz z rozwojem biologii i nauk medycznych oraz inspirującej się nimi antropologii. Z jednej strony wraz z pojawieniem się koncepcji pozytywistycznych (Charles Darwin, Herbert Spencer i inni) dokonał się ogromny postęp w badaniach nad budową i funkcjonowaniem ludzkiego ciała. Z drugiej strony w filozofii przełomu XIX i XX wieku i w pierwszej połowie XX wieku zaznaczyły się tendencje antypozytywistyczne, m.in. nurt filozofii życia (Wilhelm Dilthey, Henri Bergson), narodziny fenomenologii i antropologii filozoficznej (Edmund Husserl, Max Scheler, Helmuth Plessner, Arnold Gehlen i inni) oraz egzystencjalizmu (Martin Heidegger, Carl Jaspers, Jean-Paul Sartre). Ich wspólnym wyznacznikiem było przekonanie o odrębności sfery tego, co psychiczne, wobec fizjologicznego podłoża ludzkiego ciała. Do tych filozoficznych nurtów nawiązuje dzisiaj wiele wspomnianych powyżej odmian psychiatrii „humanistycznej”. Jej przedstawiciele formułują szereg argumentów na rzecz efektywności psychoterapii, która stawia sobie za cel oddziaływanie w rozmowie

${ }_{9}$ Platon, Obrona Sokratesa, przeł. W. Witwicki, PWN, Warszawa 2005. 
z pacjentem na treść jego przeżyć psychicznych i jego stosunek do siebie. Wskazują oni na to, że zaburzenia w tej sferze pozostają w ścisłym związku z zakłóconym samorozumieniem pacjenta i nie można ich traktować jako prostej funkcji procesów fizjologicznych zachodzacych w ludzkim ciele.

W psychiatrii XX-wiecznej nurt „deterministyczny” został zapoczątkowany przez wspomnianego już Kraepelina i z czasem zaczął w niej odgrywać coraz większą rolę. Dzisiaj jest to nurt dominujacy. Natomiast za jednych z najbardziej znaczących pionierów nurtu „humanistycznego" można uznać Sigmunda Freuda i Carla Gustava Junga. Obydwaj w swoich psychoanalitycznych teoriach nadali nowe znaczenie pojęciu autonomii tego, co psychiczne, wskazując na kluczowe znaczenie w nim treści nieświadomych. Komplikowało to dotychczasowy obraz ludzkiego życia psychicznego, w którym zostały wyszczególnione dwa niewspółmierne ze sobą systemy, nazywane świadomością i nieświadomym. Systemy te Freud i Jung traktowali jako odniesione do siebie, czyli pozostające z jednej strony w różnorakich antagonistycznych relacjach, z drugiej - implikujące się nawzajem. W obu tych teoriach stan psychicznej „normalności” czy „zdrowia” znamionowała względnie trwała równowaga czy kompromis między tymi dwoma systemami psychicznymi, podczas gdy zaburzenia psychiczne manifestujące się w postaci symptomów były efektem naruszenia owej równowagi. Ostatecznie pojęcia „zdrowia” czy „choroby” życia psychicznego były traktowane tutaj jako zależne od sposobu odniesienia świadomości do nieświadomego, mimo że obydwaj ojcowie psychoanalizy pojmowali to w odrębny sposób.

Nowe ujęcie sfery psychicznej człowieka kazało Freudowi i Jungowi opracować nową metodę psychoterapii, nazywaną przez nich psychoanalizą. Mimo wszelkich głębokich różnic, wspólne im było, że owa metoda miała koncentrować się wyłącznie na „analizie” ludzkiej psychiki, której efektem miało być przeobrażenie relacji między świadomością i nieświadomym. Teorie Freuda i Junga były potem często łączone z elementami 
wspomnianych powyżej antypozytywistycznie zorientowanych koncepcji filozoficznych, co owocowało powstaniem w psychiatrii szeregu nowych nurtów „humanistycznych”, które włączały w metodykę swego postępowania elementy teorii i praktyki psychoanalitycznej (np. logoterapia, Daseinsanalyse, różnego typu terapie egzystencjalne, psychodynamiczne).

Pojawienie się tych skrajnie odmiennych metod w psychoterapii XX wieku sprawiło, że spory o to, które z nich są bardziej skuteczne, przybrały nową postać. Możemy to wyraźnie zaobserwować, śledząc pojawienie się z jednej strony w polskiej psychiatrii i psychoterapii na początku XX wieku i w międzywojniu „deterministycznych” podejść, wychodzących od koncepcji Kraepelina (Samuel Goldflam, Edward Flatau, Jan Mazurkiewicz, Władysław Sterling), z drugiej zaś tendencji „humanistycznych”, inspirowanych przez Freudowską i Jungowską psychoanalizę (Adam Wizel, Jan Nelken, Maurycy Bornsztajn, Gustaw Bychowski). Widać to wyraźnie, jeśli prześledzi się dyskusje na zjazdach psychiatrów polskich w tym okresie. W latach trzydziestych pojawiają się też u niektórych (Maurycy Bornsztajn, Gustaw Bychowski) nowatorskie tendencje do kompleksowego uwzględniania w procesie terapii roli zarówno czynników somatycznych, jak i psychicznych odpowiedzialnych za powstawanie choroby.

W artykule tym chciałbym pokazać, w jaki sposób na mapie ówczesnych tendencji w psychiatrii i psychoterapii próbował w latach dwudziestych określić swoją pozycję Roman Markuszewicz, jeden z najwybitniejszych międzywojennych neurologów i psychiatrów orientacji psychoanalitycznej. Punktem wyjścia moich rozważań będzie jego obszerny artykuł z 1926 roku, Psychoanaliza $i$ jej znaczenie lecznicze ${ }^{10}$. Zaprezentował on w nim stanowisko typowe dla ówczesnych zwolenników teorii Freuda, kładąc nacisk na kluczowe znaczenie doprowadze-

10 R. Markuszewicz, Psychoanaliza $i$ jej znaczenie lecznicze, „Warszawski Kalendarz Lekarski” 1926, s. 269-338. 
nia do przeobrażenia samowiedzy pacjenta w procesie terapii. Opowiedział się on w nim tym samym za „humanistycznym” modelem terapii, jakkolwiek poddał w nim krytyce zarówno tradycyjne metody tego typu, jak i nowoczesne podejścia, inspirujace się deterministyczną teorią Kraepelina.

Chciałbym bliżej przyjrzeć się argumentom Markuszewicza i wydobyć filozoficzne założenia, jakie tkwią u ich podstaw. Najpierw jednak wypadałoby przybliżyć w kilku zdaniach sylwetkę tego zapomnianego dzisiaj przedstawiciela polskiej psychiatrii i psychoterapii.

\section{3.}

Roman Markuszewicz urodził się w 1894 roku w Warszawie w zasymilowanej rodzinie żydowskiej. Studia odbył na Uniwersytecie Jagiellońskim i w Zurychu, gdzie w 1921 roku uzyskał tytuł doktora medycyny. Podstawą była praca z dziedziny neurologii, której promotorem był wybitny niemiecko-szwajcarski patolog Hermann Eichhorst. W trakcie studiów w Zurychu Markuszewicz pracował w Institut der Anatomie des Gehirns, kierowanym przez Constantina von Monakowa, wybitnego neurologa o polskich korzeniach, oraz w klinice neurologicznej u Emila Redlicha. Z psychoanalizą Freudowską zapoznał się bliżej w trakcie pracy w klinice Juliusa Wagnera-Jauregga w Wiedniu, gdzie przebywał w latach 1921-1924. W 1924 roku, po powrocie do kraju, nostryfikował dyplom i zaczął prowadzić prywatną praktykę w Warszawie jako neurolog i psychiatra.

Przez cały okres do wybuchu II wojny światowej był blisko związany ze środowiskiem lekarskim Szpitala Starozakonnych na Czystem w Warszawie. Szczególne więzy przyjaźni łączyły go z ordynatorami tego szpitala, Adamem Wizlem i Maurycym Bornsteinem (Bornsztajnem). Wśród warszawskich lekarzy psychiatrów, którzy w swojej klinicznej praktyce preferowali podejście psychoanalityczne, Markuszewicz cieszył się - obok Gustawa Bychowskiego - bodaj największym autorytetem. 
Zawdzięczał go swojej intelektualnej samodzielności w podejmowaniu złożonej problematyki psychoterapii, co znalazło najbardziej wymowny wyraz w jego ambitnym projekcie rewizji podstawowych pojęć teorii Freuda. Uważał ją za najbardziej owocną współczesną teorię psychiatryczną, zgłaszał jednak pod jej adresem wiele krytycznych uwag, wskazując na szereg zawartych w pracach autora Totem i tabu niekonsekwencji, niedomówień i sprzeczności. Celem było wypracowanie „właściwej” teorii psychoanalitycznej w oparciu o te założenia i wątki prac Freuda, które uznał za najcenniejsze. Opublikowane przez Markuszewicza artykuły po polsku i po niemiecku złożyłyby się dzisiaj na całkiem okazały, jednolity tom.

Wojnę udało mu się, wraz z żoną, przeżyć, gdyż zataił przed Gestapo żydowskie pochodzenie. Swoje perypetie w latach 1939-1945 opisał w pamiętniku Cudowne ocalenie, którego fragmenty ukazały się w języku angielskim ${ }^{11}$. To jeden $\mathrm{z}$ najbardziej wstrząsających dokumentów tamtego czasu. Markuszewicz opisuje w nim przesłuchania przez Gestapo, a także różne formy szantażu stosowane wobec niego przez polskich szmalcowników. Markuszewicz zmarł w 1946 roku.

4.

Wspomniany artykuł Markuszewicza opublikowany został w „Warszawskim Kalendarzu Lekarskim”. Była to, po książce Jekelsa Szkic psychoanalizy Freuda z 1912 roku, pierwsza tak obszerna, bo blisko 70-stronicowa publikacja w języku polskim, której autor prezentując własne rozumienie procesu terapii przybliżał równocześnie czytelnikom podstawowe założenia teorii Freuda.

Warszawski psychiatra zaczyna swoją rozprawę od usytuowania teorii psychoanalitycznej Freuda na tle dotychczasowej

11 R. Markuszewicz, A Miraculous Escape. Recollection of a Survival of the Holocaust, przeł. J. Hammond, Beecroft, Australia 1976. 
tradycji psychoterapii. Według Markuszewicza na tę tradycję składają się dwa nurty. Pierwszy z nich, mający swe korzenie $\mathrm{w}$ czasach zamierzchłych, to leczenie zaburzeń psychicznych za pomocą wiary. Tę formę leczenia praktykowali starożytni kapłani, którzy starali się wpływać na chore ludzkie dusze poprzez rozbudzanie w nich wiary w bogów. Dzisiaj ten typ terapii uprawia się jednak w Europie - zaznacza autor - marginalnie, w gminach typu Christian Science; z kolei austriacki antropozof, wizjoner i gnostyk Rudolf Steiner zaleca pacjentom połykanie „cudownego” preparatu chemicznego, ponoć o oddziaływaniu leczniczym. Inna wersja to model terapii oparty na autosugestii, zaproponowany przez Émile'a Couè, który każe chorym nieustannie powtarzać zdanie, że cierpienie przejdzie. Popularnością w zapadłych i zacofanych regionach wiejskich cieszą się też ludowe wersje terapii przez wiarę, w których funkcję terapeutów pełnią znachorzy. Drugi nurt w psychoterapii jest już ściśle powiązany z nowoczesną nauką europejską i ma postać „psychoterapii racjonalnej”. Swój początek wzięła ona „z badań nad hipnotyzmem i sugestią: przekonano się bowiem, że za pomocą sugestii, stosowanej bądź w hipnozie, bądź na jawie, można nie tylko wywoływać, ale i usuwać te lub inne objawy psychonerwicy" ${ }^{2}$.

$\mathrm{W}$ nieco zmienionej postaci ten typ psychoterapii pojawia się w teoriach Paula-Charles'a Dubois i Josepha Jules'a Dèjerine'a, którzy sugestię zastępują perswazją na jawie. Inna jej wersja to koncepcja „reedukacji” Pierre'a Janeta, gdzie próbuje się oddziaływać słowami na intelekt i sferę emocjonalną pacjenta. Wyróżnikiem wszystkich tych koncepcji jest to, że istotną rolę odgrywa w nich autorytet lekarza.

Na tle tej tradycji psychoanalizę Freuda wyróżnia wypracowanie modelu psychoterapii:

12 R. Markuszewicz, Psychoanaliza..., s. 269. 
opartej na poznaniu tych mechanizmów psychicznych, które doprowadziły do powstania psychonerwicy. Dotychczas bowiem, stosując metody sugestywne, nie zdawano sobie bynajmniej sprawy z tego, co się właściwie leczy, na czym polega choroba psychogenna. Wobec psychonerwicy zachowywano się stale, jak wobec rany $\mathrm{w}$ epoce przed Listerem: obawiano się jej dotknąć, ażeby nie spowodować jeszcze większego zakażenia. Podobnie postępowano z chorym, cierpiącym na psychonerwicę: nie mówiono nic z nim o jego ranie psychicznej, o przeżyciach i wstrząsach, które do choroby nerwowej doprowadziły, temat ten, żeby „nie denerwować chorego” pomijano starannie milczeniem, zaś metody psychoterapeutyczne, jak sugestia, perswazja, hipnoza, starały się odwrócić tylko uwagę chorego od tego, co było treścią jego cierpienia. A wobec tego nie tylko nie poznawano choroby psychogennej [...] - ranę psychiczną tylko powierzchownie starano się zagoić, pozostawiając pod cienką warstwą pozornego zdrowia ognisko chorobowe, jątrzyło $\mathrm{w}$ dalszym ciągu psychikę tak długo, aż pod postacią innego objawu nie przejawiało się ponownie na zewnątrz ${ }^{13}$.

Inaczej zatem niż Freud, wspomniane powyżej współczesne metody „psychoterapii racjonalnej” nacisk kładą na ozdrowieńczą moc dyskursu lekarza, który posługując się sugestią, perswazją lub hipnozą zaszczepia pacjentowi wiarę w wyzdrowienie, nie dociekając źródeł jego choroby. Od tradycyjnych form psychoterapii różnią się one tylko tym, że pacjent nadzieję na swe wyzdrowienie pokłada w wierze w autorytet lekarza ${ }^{14}$. Słabością tego typu metod jest według Markuszewicza to, że odnoszą się one jedynie do objawów choroby, nie dociekając ich przyczyn.

13 Tamże, s. 269-270.

14 Przeciwstawienie przez Markuszewicza psychoanalizy Freuda metodom terapii przez sugestię i perswazję opartym na autorytecie lekarza różni się od sposobu, w jaki ich relację do siebie ujął Michel Foucault w $\mathrm{Hi}$ storii szaleństwa. W jego przekonaniu psychoanaliza również opiera się na perswazji i sugestii, za co ją ostro krytykuje (por. M. Foucault, Historia szaleństwa $w$ dobie klasycyzmu, przeł. H. Kęszycka, PIW, Warszawa 1987, s. 456-459). Kiedy czytamy artykuł Markuszewicza, trudno nie dostrzec, że ta interpretacja psychoanalizy przez Foucaulta jest nieporozumieniem. 
Wymagałoby to bowiem odniesienia się przez psychoterapeutę do traumatycznych wydarzeń z przeszłości pacjenta, które stały się źródłem jego cierpień. A to właśnie należy wykluczyć.

Zarówno zatem tradycyjne leczenie wiarą, jak leczenie sugestią, perswazją i hipnozą jest $\mathrm{w}$ istocie rodzajem ucieczki przed zgłębieniem prawdziwych źródeł choroby. Terapeutyczny efekt miałby być osiągnięty poprzez wytwarzanie różnego typu iluzji, a nie poprzez dotarcie do źródeł choroby. Dlatego efekty tego typu terapii są albo żadne, albo w najlepszym wypadku krótkotrwałe i kruche.

Ostatecznie różnica między modelem leczenia przez wiarę czy przez perswazję, gdzie funkcję terapeutyczną ma spełnić wiara pacjenta w Boga lub w autorytet lekarza, a podejściem psychoanalitycznym polega na tym, że w tym drugim wypadku wyleczenie może nastąpić poprzez refleksyjny namysł nad sobą. Pacjent ma w trakcie terapii skonfrontować siebie z tym, co sam wyparł w nieświadome, a nie podeprzeć się autorytetem innego, pozostawiając swój stosunek do siebie w stanie nienaruszonym.

W psychoanalizie pobudzenie ozdrowieńczych tendencji tkwiących w ludzkiej psychice jest równoznaczne $\mathrm{z}$ - twierdzi Markuszewicz - pobudzeniem pacjenta do wglądu w siebie. W trakcie terapii należy tylko w odpowiedni sposób pokierować tymi tendencjami, pozostawiając pacjentowi swobodę w interpretowaniu własnych symptomów. Równocześnie pacjent ma odnieść się w nowy sposób do własnych relacji z innymi, angażując w te relacje całą swoją osobowość. Natomiast w modelu leczenia przez wiarę czy perswazję lekarza liczy się jedynie wiara pacjenta $\mathrm{w}$ zewnętrzną instancję, a nie on sam. W rezultacie ignoruje się tu te czynniki, które legły u podłoża jego zaburzeń psychicznych i związane były z jego zaburzonymi relacjami z innymi.

Według Markuszewicza zatem Freud opracował po raz pierwszy metodę terapii, opierającą się na dążeniu do poznania prawdziwych przyczyn choroby, które tkwią u podłoża jej 
objawów. Psychoterapeuta nie odwraca się tu od tych objawów, apelując jedynie do wiary chorego lub każąc mu wierzyć w magiczne moce ozdrowieńcze lekarza, lecz dąży do poznania źródeł jego cierpienia. Dlatego metoda ta nie zadowala się:

leczeniem tylko objawowym, lecz dąży głębiej, do usunięcia tych konfliktów psychicznych, które spowodowały powstanie objawów. [...] Freud po raz pierwszy nie zadowolił się badaniem tylko objawu chorobowego, lecz sięgnął głębiej - do chorej osobowości, ażeby leczyć nie tylko chorobę, lecz samą osobowość.

Ta celowość, z jaką dążył Freud do zgłębienia genezy psychonerwicy, zmieniła stosunek lekarza do stosowanej przez siebie metody psychoterapeutycznej. Dzięki poznaniu bowiem nie stał już lekarz bezradnie przed ciągle frapująca go zagadką psychonerwicy, lecz, opierając się na zdobytym poznaniu, mógł zrozumieć [podkr. P.D.] chorego; stosując zaś metodę terapeutyczną psychoanalizą zwaną, stosował ją świadomie, celowo zmierzając do źródła choroby. [...] W ten bowiem sposób zostaje skierowana uwaga i chorego i lekarza na drogę właściwą, t.j. na indywidualność chorego [podkr. P.D.], a nie na objaw, który jest tylko tarczą ochronną, pokrywającą konflikty psychiczne chorego ${ }^{15}$.

Ostatecznie wyższość metody psychoanalitycznej nad innymi współczesnymi metodami psychoterapii polega na dociekaniu genezy chorobowych symptomów, których korzenie tkwią $\mathrm{w}$ nieświadomym. Obierając to podejście, terapeuta stara się dotrzeć do źródła konfliktów, które zrodzone przez traumatyczne wydarzenia w przeszłości pacjenta, zostały przez niego wyparte, podczas gdy symptomy („objawy”) sa jedynie zewnętrznym śladem po tym wyparciu.

Terapeuta psychoanalityk opuszcza, według warszawskiego psychiatry, powierzchnię zjawisk świadomych na rzecz poszukiwania ich źródeł w nieświadomym. Sięga on w psychikę pacjenta głębiej, niż to czyniono dotychczas. Konfrontując go

${ }^{15}$ R. Markuszewicz, Psychoanaliza..., s. 270-271. 
z wydarzeniami z przeszłości, które ten wyparł w nieświadome, otwiera przed nim możliwość uwolnienia się od nich. Podejście to implikuje, że pacjent musi w trakcie terapii poznać rzeczywiste przyczyny swego cierpienia i je przepracować, a nie odwracać się od nich i traktować jako możliwe do usunięcia jedynie poprzez zdanie się na wiarę w kojące słowa lekarza.

W tym ujęciu zadanie lekarza analityka polega na poznaniu źródeł wypartych przez pacjenta konfliktów. To zaś oznacza, że terapia psychoanalityczna zawiera $\mathrm{w}$ sobie elementy podejścia hermeneutycznego: analityk ma na drodze interpretacji symptomów pacjenta zrozumieć naturę jego choroby. Zrozumienie to implikuje zarazem, że wyparte przez pacjenta konflikty odnoszą się nie tylko do objawów chorobowych, lecz rzutują na całą jego osobowość. Analityk leczy nie tylko chorobę pacjenta, usuwajac jej symptomy, lecz wraz z tym zmienia gruntownie jego osobowość - jego samorozumienie. W przypadku chorób i zaburzeń psychicznych nie sposób od siebie oddzielić tego, co zdrowe i tego, co chore w psychice jednostki. Działa tutaj zasada „koła hermeneutycznego”. Zaburzenie jako część rzutuje na całość życia psychicznego pacjenta, a zarazem wszystko to, co dzieje się z tą częścią w procesie terapii, musi znaleźć swoje nowe miejsce w obrębie przekształconej całości. Innymi słowy, doprowadzając do zaniku symptomów pacjenta, analityk doprowadza do zintegrowania tego, co było ich przyczyną i uległo wyparciu, na nowo z samowiedzą pacjenta. To zaś prowadzi do zmiany owej samowiedzy.

Oba te aspekty procesu terapii są ściśle ze sobą powiązane. Uwolnienie pacjenta od symptomów może dokonać się jedynie wówczas, gdy ten zmieni stosunek do samego siebie. Terapia zakłada zmianę jego stosunku do wypartego w nieświadome źródła własnych symptomów, którym jest zazwyczaj traumatyczne wydarzenie z przeszłości. Zrodziło ono w pacjencie głęboki konflikt, który został przez niego wyparty. Potem nałożyły się nań konflikty inne, związane z innymi wydarzeniami, które też zostały wyparte. 
Markuszewicz podkreśla, że aby dotrzeć do tych wypartych konfliktów i zdiagnozować ich źródła, analityk musi przezwyciężyć opór ze strony pacjenta. W trakcie terapii porusza bowiem jego „najgłębsze i najintymniejsze przeżycia”, których ten jest nie tylko nieświadom, ale zrazu broni się ze wszystkich sił przed ich uświadomieniem. Zadanie to wymaga od analityka nie tylko technicznych umiejętności prowadzenia rozmowy terapeutycznej, ale i ogromnego wyczucia, gdyż każdy przypadek jest szczególny. Freud, zdając sobie sprawę z tych trudności, uznał, że niezbędnym elementem kształcenia analityków winna być autoanaliza, której musi się poddać każdy kandydat. Dopiero gdy sam doświadczy bolesnej konfrontacji z wypartymi przez siebie konfliktami i je przepracuje, będzie w stanie efektywnie przeprowadzić terapię pacjenta.

Markuszewicz wskazuje w swoim artykule na znaczenie tego metodycznego wymogu, ustanowionego przez Freuda w latach dwudziestych w ramach International Psychoanalytic Association (IPA). Ponieważ nie powstało w Polsce w okresie międzywojnia towarzystwo psychoanalityczne, w którym by szkolono kandydatów na analityków, trudno jest dzisiaj na podstawie zachowanych świadectw stwierdzić, czy - a jeśli, to w jaki sposób - Markuszewicz przeszedł przez doświadczenie autoanalizy. Nie był on członkiem żadnego towarzystwa psychoanalitycznego należącego do IPA ${ }^{16}$. Inna sprawa, że sposób, w jaki pisze o tym metodycznym wymogu Freuda, świadczy o tym, że upatrywał w nim jednego z niezbędnych warunków wykształcenia analitycznego.

Według Markuszewicza pacjent powinien w trakcie terapii poznać prawdę o sobie, zrywając maski pozornych samousprawiedliwień. W tym kontekście autor artykułu powołuje się na zdanie Nietzschego, który stwierdzając, że w każdym człowieku jest sporo samozakłamania, pisał: „To oto uczyniłem, twierdzi

${ }^{16}$ Jedynym psychoanalitykiem polskim, który należał do Wiedeńskiego Towarzystwa Psychoanalitycznego, był Gustaw Bychowski. 
moja pamięć; niemożliwe jest, abym to uczynił, twierdzi moja duma - i pamięć ustępuje"17. Zgodnie z tym ujęciem terapia psychoanalityczna, dokonując się w imię „pamięci”, ma pomóc pacjentowi w poznaniu prawdy o sobie, która została wyparta przez niego w nieświadome. Docieranie do tej prawdy dokonuje się w ramach perspektywy genealogicznej: rozumienie objawów chorobowych pacjenta odbywa się na drodze zgłębiania ich genezy w przeszłości pacjenta: „To wytrwałe poszukiwanie odpowiedzi na zapytanie: dlaczego? - jest punktem wyjścia całego psychoanalitycznego badania. Z tym zapytaniem przystępujemy do każdego zjawiska psychicznego, do każdego przeżycia chorego, starając się zrozumieć ich genezę"18.

W tym ujęciu terapia psychoanalityczna stanowi specyficzny przypadek hermeneutyki genealogicznej, w której rozumienie zasadza się na docieraniu poprzez „objawy” do wypartych wydarzeń z biografii pacjenta, będących źródłem jego konfliktów ${ }^{19}$. W podobny sposób odrębność podejścia psychoanalitycznego na tle innych technik terapii ujmowali inni przedstawiciele nurtu - Gustaw Bychowski, Maurycy Bornstein (Bornsztajn), Tadeusz Bilikiewicz i inni. Szło za tym przekonanie, że psychoanaliza jest tak specyficzną technika terapii, iż otwiera nowy rozdział w historii psychoterapii, dociekając do prawdziwych, tkwiących „głęboko” w ludzkiej psy-

${ }^{17}$ Cyt. za: R. Markuszewicz, Psychoanaliza..., s. 272.

18 Tamże, s. 273.

19 Uznanie psychoanalizy za rodzaj hermeneutyki ma długą tradycję, sięgającą prac Ludwiga Binswangera na ten temat (tenże, Ausgewählte Vorträge und Aufsätze, t. 1-2, Francke Verlag, Bern 1955). Współcześnie najbardziej znanym jest podejście zaproponowane przez Paula Ricoeura w książce $O$ interpretacji. Esej o Freudzie, przeł. M. Falski, Wydawnictwo KR, Warszawa 2008 (pisałem o tym szeroko w książce poświęconej tej problematyce, patrz: P. Dybel, Dialog i represja. Antynomie psychoanalizy Sigmunda Freuda, IFiS PAN, Warszawa 1994). Inni autorzy z kolei podkreślali genealogiczny charakter teorii Freuda, nazywając ją, jak np. Gaston Bachelard, „psychoarcheologią” (patrz: tenże, La Psychoanalyse du Feu, Gallimard, Paris 1938). 
chice przyczyn zaburzeń. Bornstein na przykład w pracy opublikowanej w 1916 roku stwierdzał, że psychoanaliza:

wychodząc z zasady, że wszystko psychiczne musi mieć swe źródło w psychice (Alles Seelische aus dem Seelischen) wprowadza niezależnie od tamtych, badania nad psychologicznym powstawaniem i uzasadnieniem poszczególnych objawów i ich zespołów, stara się je zrozumieć ze stanowiska danej jednostki, jej konstytucji psychicznej, jej przeżyć życiowych. [...] W ten sposób rozwinęła się nowa gałą́ psychologii subiektywnej, w przeciwstawieniu do psychologii eksperymentalnej, czyli obiektywnej. Część tej psychologii subiektywnej, mającej na celu wyświetlanie pochodzenia, genezy, poszczególnych treści psychicznych u chorych umysłowo w związku z przeżyciami danej jednostki, obejmuje sobą freudyzm ${ }^{20}$.

Według Bornsteina psychiatra ma leczyć chorego, koncentrując się na jego psychice, poszukując wyłącznie w jej obrębie przyczyn jego zaburzeń. Markuszewicz podpisałby się z pewnością pod tą wypowiedzią. Według niego wszelkie próby upatrywania źródeł zaburzeń neurotycznych lub schizofrenicznych w fizjologii pacjenta, w jego organach, są nieporozumieniem ${ }^{21}$. Podejście to jest tak samo zawodne, jak skrytykowane przez niego wcześniej „metody” leczenia wiarą oraz sugestią czy perswazją. Więcej nawet, jest ono szczególnie niebezpieczne dla pacjenta. Wtedy bowiem „cierpienie psychogenne zostaje traktowane jako organiczne i dzięki zabiegom stosowanym przez lekarza, wiara chorego zostaje mylnie utrwalona w tym kie-

${ }^{20} \mathrm{M}$. Bornstein, O odrębnym typie rozszczepienia psychicznego (schizothymia reactiva), Z Oddziału Psychiatrycznego w Szpitalu na Czystem, E. Wende i spółka, Warszawa 1916, s. 4-5.

${ }^{21}$ Warto tutaj podkreślić, że zarówno Bornstein (Bornsztajn) jak i Bychowski uważali, że psychoanaliza jest owocną metodą nie tylko w leczeniu neuroz, ale stanowi dobry punkt wyjścia w terapii psychoz, pozwalając zrozumieć sens ich symptomów. Bychowski później w Stanach Zjednoczonych będzie jednym z najwybitniejszych psychoanalityków zajmujących się leczeniem psychoz. 
runku, że chorą jest nie psychika, lecz narząd, który w rzeczy samej jest zdrowy. Zrozumiałe jest, że takie leczenie nie może nie być szkodliwe ${ }^{22}$.

Szkodliwość leczenia operacyjnego chorych psychicznie pacjentów polega nie tylko na tym, że opiera się ono zazwyczaj na fałszywej diagnozie, upatrując przyczyn zaburzeń nie tam, gdzie one rzeczywiście tkwią. Może ono również prowadzić do operowania narządów całkowicie zdrowych i mieć fatalne skutki dla konstytucji cielesnej pacjenta. Tak jak np. w przypadku owych amerykańskich lekarzy, którzy idąc za diagnozą Charcota, upatrującego źródła pewnego typu histerii kobiet w schorzeniu jajników, wycinali ten narząd w celu wyleczenia pacjentek $^{23}$. Jak na ironię - twierdzi Markuszewicz - wielu pacjentów woli ulegać tej iluzji. Gotowi są oni raczej poddawać się różnego rodzaju zabiegom i operacjom na swoim ciele niż na swojej psychice, którą woleliby pozostawić w stanie nienaruszonym.

5.

U podstaw psychoterapii nastawionej na leczenie psychiki pacjenta poprzez ingerencję $\mathrm{w}$ domniemane chore narządy jego ciała tkwi przekonanie, że głównym źródłem jej zaburzeń jest mózg. W tradycji polskiej psychiatrii przekonanie to zostało wypowiedziane przez Jana Piltza w wykładzie wygłoszonym przez niego z okazji otwarcia w 1905 roku Katedry Psychiatrii i Neuropatologii na UJ w Krakowie, do 1939 roku głównego ośrodka tego typu w Polsce:

Podstawą nowoczesnej psychiatrii, jako nauki przyrodniczej, opartej na doświadczeniu [...] jest fakt, że tłem organicznym wszystkich czynności psychicznych jest mózg; że w ogóle każ-

${ }_{22}$ M. Bornstein, $O$ odrębnym typie rozszczepienia psychicznego..., s. 274.

${ }^{23}$ Por. E. Trillat, Historia histerii, przeł. Z. Podgórska-Klawe, E. Jamrozik, Ossolineum, Wrocław-Warszawa-Kraków 1993, s. 117. 
dej zmianie w stanie naszej świadomości towarzyszy pewna zmiana w ośrodkowym układzie nerwowym i że choroby umysłowe są tylko objawem pewnych patologicznych zmian w mó$\mathrm{zgu}^{24}$.

Podejście to prowadziło autora wykładu do konkluzji, że:

Dusza, objawy psychiczne, czynność mózgu i czynność nerwowa - są to synonimy. [...] Psychiatria wchodzi w zakres neuropatologii, a właściwie stanowi tylko jeden rozdział neuropatologii, mianowicie ten, który traktuje o chorobach mózgu, względnie kory mózgowej ${ }^{25}$.

Piltz początkuje w polskiej psychiatrii tradycję leczenia chorób psychicznych, w której ta dziedzina nauk medycznych podporządkowana została neuropatologii, gdzie wszelkie objawy zaburzeń psychicznych traktowane sa jako zakorzenione w patologii mózgu. U podstaw tego podejścia tkwi podobny schemat teoriopoznawczy jak ten, który kazał psychiatrom wzrosłym $\mathrm{w}$ tradycji pozytywistycznej operować chore organy, będące - ich zdaniem - źródłem psychicznych zaburzeń pacjentów. Zgodnie z tym schematem, którego pierwowzór odnajdujemy u Descartes'a, ludzkie ciało, jego fizjologia (soma), stanowi podłoże wszelkiego rodzaju zjawisk i procesów psychicznych ${ }^{26}$. Dlatego, jeśli chcemy wpłynąć na te zjawiska i procesy, musimy najpierw oddziałać na to podłoże.

Otwiera się tu nie tylko perspektywa dokonywania różnego typu operacji i zabiegów na ciele pacjenta, ale również jego leczenia za pomocą leków oddziałujących na fizjologię jego ciała. Ten schemat myślenia, przejęty później przez nauki medyczne, doprowadził $\mathrm{z}$ czasem do zdominowania psychiatrii

24 J. Piltz, Stanowisko psychiatrii $w$ rzędzie innych nauk lekarskich, oraz nowoczesne jej zadania i cele, „Przegląd Lekarski” 1905, nr 30, s. 4.

25 Tamże, s. 12-13.

26 Por. R. Descartes, Namiętności duszy, przeł. L. Chmaj, PWN, Warszawa 1986. 
przez metody oparte na aplikacji pacjentowi odpowiedniego zestawu leków, które poprzez wspomaganie jednych procesów fizjologicznych i blokadę innych miały doprowadzić do usunięcia - a przynajmniej osłabienia - objawów chorobowych w psychice pacjenta. Dlatego skoncentrowano się na badaniach, mających na celu zgłębienie złożonych powiązań przyczynowo-skutkowych między psyche i soma.

Dzisiaj farmakoterapia zalecana jest przez wielu psychiatrów i stosowana powszechnie w terapii. Po leki różnego typu, które mają łagodzić zaburzenia ludzkiej psychiki, sięgają niekiedy w ostateczności również i psychoanalitycy. Na przykład gdy stwierdzają, że stan psychiczny pacjenta jest tak ciężki, iż wymaga już na początku terapii wsparcia lekami. Natomiast pozytywne efekty psychoterapii opartej na rozmowach $\mathrm{z}$ pacjentem pojawić się mogą dopiero po dłuższym czasie, co wymaga zarówno dużego samozaparcia ze strony pacjenta, jak i zazwyczaj sporego nakładu finansowego. Nic dziwnego, że farmakologiczny sposób radzenia sobie z problemami natury psychicznej stał się dzisiaj bardzo popularny. Z jednej strony jest on o wiele tańszy niż psychoterapia, trwająca wiele miesięcy, a niekiedy i kilka lat, z drugiej ze względu na jego masowość jest źródłem ogromnych zarobków firm farmaceutycznych, które finansowo wspierają te formy terapii, przeznaczając duże pieniądze na naukowe badania nad wynalezieniem nowych leków.

Markuszewicz nie wyklucza farmakoterapii, ale twierdzi, że leczenie psychiki poprzez oddziaływanie na jej fizjologiczne podłoże jest uzasadnione tylko w niektórych przypadkach. Nie uwzględnia ono jednak zazwyczaj prawdziwych przyczyn choroby psychicznej pacjenta. Ba, nie jest nawet poszukiwaniem takich przyczyn zainteresowane. Zakłada się tu bowiem, że poprzez odpowiednie operacyjne zabiegi czy kurację lekami można niejako automatycznie osiągnąć spodziewany terapeutyczny efekt. Tymczasem według Markuszewicza zaburzenia psychiczne w przytłaczającej większości wypadków nie bio- 
rą się stąd, że nastąpiło zwyrodnienie w mózgu pacjenta czy w przebiegających w nim procesach fizjologicznych. Ich właściwym źródłem są wyparte konflikty z innymi, które doprowadziły do zakłócenia relacji pacjenta $\mathrm{z}$ nimi i rzutują też na jego stosunek do siebie. Dlatego terapia za pomocą leków w odniesieniu do tego typu zaburzeń może mieć najwyżej efekt chwilowy. Sięgając po nią, możemy osłabić występowanie symptomów czy depresję jedynie tak długo, jak długo dany lek oddziałuje na fizjologię ciała pacjenta. Potem trzeba dawkę leku powtórzyć. A jeśli pacjent się uzależni od leku, może to doprowadzić tylko do pogłębienia objawów choroby. I wtedy trzeba dawkę zwiększyć. Powstaje wówczas błędne koło.

Sytuacja, w której psychiatra podaje pacjentowi lek, który poprzez fizjologię jego ciała ma oddziałać na jego psychikę, zakłada instrumentalne podejście do owej psychiki. Ciało i psychika pacjenta są traktowane tutaj niczym sprzężone ze sobą elementy maszyny, na które może on dowolnie wpływać z zewnątrz, nie angażując w procesie terapii siebie ani na jotę. Całą pracę terapeutyczną wykonuje za niego „magiczna” pigułka, która pacjent ma tylko połknąć, aby doświadczyć jej cudownie kojącego działania. Albo wprawna ręka psychochirurga.

Psychoanalityczny model terapii sytuuje się według Maruszewicza na antypodach podobnego podejścia. Opiera się on na założeniu, że u podstaw zaburzeń psychicznych pacjenta tkwią jego konflikty z innymi, które zostały wyparte w nieświadome i których jedynym pośrednim znakiem są symptomy w jego zachowaniu. Dlatego w trakcie terapii nacisk musi zostać położony na doprowadzenie do uświadomienia przez pacjenta natury tych konfliktów i skonfrontowanie go z nimi. Winien on je przepracować w swojej psychice i wykształcić wobec nich nową postawę, która pozwoli mu na swój sposób się od nich uwolnić.

Tego typu model terapii opiera się na założeniu, że w ludzkiej psychice obecne są, zawarte w niej niejako w sposób naturalny, tendencje samoozdrowieńcze, które w trakcie terapii analityk winien umiejętnie pobudzić. Kiedy zaś mu się to uda, 
wtedy może przy współpracy z pacjentem doprowadzić do usunięcia paraliżujących jego społeczną aktywność symptomów. Daje tu o sobie znać wielki optymizm warszawskiego psychiatry. I to nie tylko co do możliwości tkwiących w psychoanalitycznym modelu terapii, ale też co do ludzkiej natury. Aby te możliwości zostały urzeczywistnione, powinien jednak zostać spełniony jeden warunek: pacjent musi zdobyć się na odwagę skonfrontowania siebie z własnym nieświadomym i przepracowanie tego, co zostało tam przez niego wyparte.

Zakłada to, że na drodze samopoznania ludzka psychika może się w sposób trwały przekształcić, odzyskać jakiś rodzaj harmonijnej zgody $\mathrm{z}$ samą sobą. $\mathrm{W}$ tym punkcie sposób ujęcia terapii psychoanalitycznej przez Markuszewicza wychodzi naprzeciw wspomnianej na początku filozoficznej formuły wypowiedzianej przez Sokratesa, którą można uznać za motto wszystkich „humanistycznych” form psychoterapii. Ateński filozof uważał wprawdzie, że wszelka wiedza - również wiedza wypływająca z poznania siebie - nie przynosi szczęścia. Zarazem jednak jej podstawowej wartości upatrywał w tym, że pozbawia ona złudzeń i fałszywych mniemań, ucząc człowieka wytrwałości i konsekwencji w myśleniu oraz zachowania równowagi ducha w obliczu przeciwności losu. Na tym też zasadza się jej prawdziwie terapeutyczna funkcja. Ta sokratejska wiara w ozdrowieńcze moce wiedzy płynącej z samopoznania przebija z końcowych konkluzji omawianego tu artykułu Markuszewicza:

Leczenie bowiem psychoanalityczne ma jedną zasadniczą przesłankę: jest nią wiara w człowieka, który błądzić może tak długo tylko, póki nie pozna on świadomie w całej jaskrawości ukrytego znaczenia swych czynów i życzeń; uświadamiam choremu to wszystko w tym celu, żeby spowodować silną reakcję jego osobowości w postaci tłumienia i sublimacji ${ }^{27}$.

${ }^{27}$ R. Markuszewicz, Psychoanaliza ..., s. 347-348. 
Sokrates twierdził, że wszelkie zło w ludzkich zachowaniach i czynach wynika z niewiedzy, podobnie Markuszewicz wierzy $\mathrm{w}$ to, że kiedy pacjent $\mathrm{w}$ analizie pozna ukryte znaczenie swoich czynów i życzeń, przestanie żywić się iluzorycznymi wyobrażeniami na temat siebie i innych i zacznie postępować właściwie. W sokratejskim modelu do samopoznania partnera dialogu może dojść dopiero dzięki odpowiedniemu pokierowaniu tego dialogu przez Mistrza, w psychoanalizie analogiczną rolę pełni analityk. Ale zarysowują się też głębokie różnice. W oczach Ateńczyka samopoznanie wynika z czysto intelektualnego wglądu filozofa w złożoną naturę kluczowych w życiu obywatela polis pojęć: sprawiedliwości, dobra, piękna itd. Cały proces dochodzenia do prawdziwego znaczenia tych pojęć przebiega na poziomie świadomości. W modelu terapii psychoanalitycznej natomiast proces samopoznania ześrodkowany jest wokół wglądu w nieświadome. Przebiega więc w sposób okrężny i dotyczy głównie wypartych przez pacjenta traumatycznych wydarzeń z przeszłości.

Kolejna różnica dotyczy sposobu, w jaki w obu przypadkach rozumie się przemianę samowiedzy partnera rozmowy pacjenta. Według Ateńczyka przemiana ta polega porzuceniu przez rozmówcę płytkiej postawy „wszechwiedzącego”, opierającego swoją argumentację na nieuzasadnionych mniemaniach (poziom elenktyczny), które łatwo jest podważyć. W zamian ma on udać się wraz z Sokratesem w drogę poszukiwania wiedzy prawdziwej, w trakcie której winien wykazać się ostrożnością w formułowaniu twierdzeń i żelazną konsekwencją w stawianiu pytań (poziom majeutyczny). Dopiero wówczas otwiera się przed nim szansa uzyskania poznania o charakterze pewnej i trwałej prawdy.

Według Markuszewicza natomiast przemiana, jaka zachodzi w osobowości pacjenta w trakcie terapii psychoanalitycznej, polega na uwolnieniu go od konfliktów wewnętrznych poprzez uświadomienie mu ich przyczyn. $\mathrm{W}$ rezultacie: 
jednostka, która przedtem zużytkowała swe siły psychiczne na bezowocną walkę wewnętrzną, staje się obecnie pożytecznym członkiem społeczeństwa, gdyż nakazy jego uzgodniła $\mathrm{z}$ własnymi popędami. [...] A zatem psychoanaliza, uzdrawiając chorego, nie tylko wyzwala go z cierpień, lecz czyni go zdolnym do rozkoszy osobistej, do pracy społecznej - słowem, daje społeczeństwu osobnika, który może być szczęśliwy. A jest to dar tak wielki, że usprawiedliwia i wynagradza tę wielką pracę wewnętrzną, z jaką jest związane poznanie samego siebie ${ }^{28}$.

Warszawski analityk wierzy w to, że już samo uświadomienie przez pacjenta wypartych przez siebie przyczyn konfliktów psychicznych ma moc uzdrowicielską. Dzięki temu może dojść do ustanowienia swego rodzaju harmonii między wymogami społecznymi wobec pacjenta (zakazy) a jego popędami. Dopiero wówczas może on stać się na powrót pożytecznym członkiem społeczeństwa, a zarazem osiąnąć szczęście osobiste. Poznanie samego siebie, które dokonuje się w trakcie analizy, ma według Markuszewicza nie tylko czynić człowieka szczęśliwym, ale i przywracać go społeczeństwu.

To z pewnością bardzo optymistyczne spojrzenie na proces psychoanalitycznej terapii. Nawet jeśli Freud w pierwszych latach swojej terapeutycznej praktyki wierzył w cudowną ozdrowieńczą moc uświadomienia sobie przez pacjenta wypartych treści jego nieświadomości, to z biegiem lat zdawał sobie coraz bardziej sprawę z tego, że na tym terapia się nie kończy. Po pierwsze bowiem, zazwyczaj na nieświadome składa się wiele wyparć, które nakładają się warstwowo jedne na drugie. W rezultacie często zanik symptomów pacjenta i jego polepszone samopoczucie okazują się chwilowe, trzeba wtedy sięgnąć głębiej w przeszłość pacjenta i zidentyfikować kolejne wyparcia. Po drugie, wraz z uświadomieniem wypartych treści powinno nastąpić ich emocjonalne odreagowanie

28 Tamże, s. 348. 
przez pacjenta (die Abreagierung, acting out). Równocześnie pacjent powinien zdać sobie sprawę z tego, że wyparte treści stanowią organiczną część jego własnej duchowej biografii. Dlatego winien je odpowiednio przepracować, zyskując wobec nich refleksyjny dystans. Innymi słowy, ma on na drodze przemyślenia na nowo własnej przeszłości i relacji z innymi zneutralizować dotychczasowe negatywne oddziaływanie tych treści na własną psychikę. A to nie zawsze się udaje do końca. Po trzecie zaś, w przypadku pacjentów psychotycznych zawodzi model terapii, opracowany przez Freuda na podstawie zaburzeń o charakterze neurotycznym. W dodatku zazwyczaj utrwalenie pozytywnych wyników terapii wymaga zmiany otoczenia rodzinnego czy społecznego pacjenta, w którym tkwią paraliżujące go psychicznie źródła jego zaburzeń. W związku z tym z czasem w ramach psychoanalizy i innych „humanistycznych” nurtów psychoterapii wykształcą się formy terapii grupowej, w których uczestniczyć będą całe rodziny czy grupy pacjentów.

Ale jakkolwiek uświadomienie sobie przez pacjenta wypartych treści może w niektórych przypadkach mieć ograniczone znaczenie lub być bez znaczenia, stanowi ono we Freudowskim modelu terapii jeden $\mathrm{z}$ podstawowych celów, jaki ma być uzyskany w jej trakcie. Podkreślając jego kluczowe znaczenie w ramach tego modelu, Markuszewicz zauważa, że wielu pacjentów właśnie z tego powodu woli zdać się na leczenie farmakologiczne czy psychochirurgiczne, niż poddać się psychoanalizie. W przebiegającej zgodnie z podobnymi założeniami terapii psychoanalitycznej ma się wszak dokonać konfrontacja pacjenta z najbardziej wstydliwymi treściami własnej psychiki, o których wolałby on nie wiedzieć. Tymczasem w farmakoterapii leczenie odbywa się bez udziału samowiedzy pacjenta. W dodatku terapia psychoanalityczna i inne formy psychoterapii trwaja zazwyczaj miesiącami (a niekiedy latami) i sa kosztowne. Dlatego wielu pacjentów nie może się na nie zdecydować, dzisiaj zaś rezygnuje się w nich z podobnego powodu 
w wielu placówkach lekarskich, ograniczając liczbę psychoterapeutów.

Markuszewicz w swym optymistycznym przekonaniu o tkwiących w ludzkiej naturze samoistnych tendencjach ozdrowieńczych zabsolutyzował z pewnością znaczenie dokonującego się w analizie refleksyjnego wglądu pacjenta we własne nieświadome. Podobnie uczyni to kilkadziesiąt lat później Jürgen Habermas, który w pracy Erkenntnis und Interesse uzna, że element krytycznej refleksji zawarty w procesie psychoanalitycznym odgrywa tu kluczową rolę ${ }^{29}$. Pod tym względem warszawski psychiatra był z pewnością bliższy Sokratesowi niż Freudowi, którego cechował duży sceptycyzm co do tezy o wrodzonej dobrej naturze człowieka. No i z czasem proces uświadamiania nieświadomego uznał jedynie za jeden $\mathrm{z}$ wielu komponentów procesu terapii psychoanalitycznej, który często o niczym jeszcze nie rozstrzyga.

6.

Orientacja współczesnej psychologii, a za nią psychiatrii i różnych form terapii, na panujące w naukach przyrodniczych metody eksperymentalne, oznacza dominację w tych trzech dziedzinach sposobu myślenia o ludzkiej psychice i jej związkach z fizjologią ciała, który zapoczątkował Descartes, a później uległ on rozwinięciu i przeformułowaniu w XIX-wiecznym pozytywizmie. U podstaw tego sposobu myślenia o ludzkiej psychice tkwi założenie, że określają ją mechanizmy i prawa, które dają się ustalić na drodze doświadczalnej i podobnie jak prawa określające byt przyrodniczy mają uniwersalny charakter. Tylko taki sposób postępowania uznaje się tu za prawdziwie naukowy, bo uzyskany na drodze eksperymentu i falsyfikowalny empirycznie. W oparciu o zdobytą w ten sposób wiedzę próbuje

${ }^{29}$ J. Habermas, Erkenntnis und Interesse, Suhrkamp, Frankfurt am Main 1965. 
się później opracować różnorakie wiarygodne naukowo strategie terapii, w ramach których dominują farmakoterapia i psychochirurgia.

Na gruncie tego stanowiska za nienaukowe uchodzą wszelkiego typu „humanistyczne” nurty i szkoły psychologiczne, psychiatryczne i psychoterapeutyczne, w których zakłada się, że przeżycia psychiczne mają zawsze w oczach jednostki określony sens, współwystępując często z przeżyciami o charakterze egzystencjalnym, w których dają o sobie znać różnego rodzaju lęki, załamania, depresje itd. Dlatego w tych szkołach i nurtach przyjmuje się, że terapia powinna być ześrodkowana na rozmowie z pacjentem, której efektem ma być zmiana jego stosunku do siebie i do innych. Przy czym sam przebieg tej rozmowy, jej treść, założony efekt itd. w zależności od metodycznych założeń danej szkoły wyglądać może bardzo odmiennie. Ponieważ ujęty w ten sposób proces terapii trudno jest zweryfikować za pomocą kryteriów wypracowanych w oparciu o metody eksperymentalne, wyciaga się stąd wniosek, że efekty tego procesu są ze swej istoty mocno wątpliwe, gdyż nie są oparte na twardych empirycznych danych.

$\mathrm{Na}$ początku tego artykułu wymieniłem przykładowo szeroką gamę tych mocno podejrzanych naukowo „humanistycznych" koncepcji, począwszy od teorii Gestalt, poprzez psychoterapię Rogersa, koncepcje egzystencjalne, fenomenologiczne, hermeneutyczne, po różne odmiany psychoanalizy i koncepcje psychodynamiczne. Mimo często głębokich między nimi różnic, ich wspólnym rysem jest uznanie, że wspomniana domena ludzkich przeżyć psychicznych, obdarzonych sensem i nacechowanych egzystencjalnie, musi być potraktowana jako autonomiczna w odniesieniu do soma, czyli do ich biologicznego podłoża. Panują tu bowiem zupełnie innego rodzaju reguły powiązania ze sobą tych przeżyć niż te, które dotycza ciała i wszelkich form materii organicznej. To założenie można nazwać hermeneutycznym w najbardziej ogólnym tego słowa znaczeniu, gdyż implikuje ono, że wszelkiego typu zaburzenia 
psychiczne winny być rozpatrywane jako zakłócenia w sferze sensu i odsyłają do samorozumienia pacjenta.

Na przykładzie wczesnego tekstu Romana Markuszewicza, jednego z najciekawszych polskich psychiatrów i psychoterapeutów międzywojnia, starałem się pokazać, jak w jego interpretacji metody terapeutycznej Freuda owo „hermeneutyczne” założenie dochodzi do głosu. Cały ciężar terapii przebiegającej zgodnie z tą metodą spoczywa według warszawskiego psychiatry na odpowiednim rozpoznaniu znaczenia symptomów pacjenta, które dochodzą do głosu w jego wypowiedziach i zachowaniu, oraz dokonaniu ich właściwej interpretacji ze względu na dochodzące w nich pośrednio do głosu treści wyparte w nieświadome. Na dalszym etapie analityk musi umiejętnie podać własną interpretację pacjentowi, tak aby ten ją przyjął i odpowiednio przepracował. Ponieważ zazwyczaj owe wyparte treści dotyczą wspomnień związanych z traumatycznymi wydarzeniami z przeszłości, których uświadomienie jest dla pacjenta bolesnym procesem, zrazu przejawia on duży opór przed ich przyjęciem do wiadomości. Kiedy jednak wszystkie jego opory zostaną przezwyciężone, konflikt (lub konflikty), który tkwił u podłoża jego psychiki, ulega rozwiązaniu. Pacjent wypracowuje nowy rodzaj rozumienia siebie i innych, uwalniając w sobie zablokowane do tej pory energie życiowe, wracając do psychicznego zdrowia. I do społeczeństwa.

Ujęty się w ten sposób przez Markuszewicza przebieg procesu terapii psychoanalitycznej uległ naturalnie sporemu uproszczeniu. Pominięta została cała jego dramaturgia i szereg powikłań, jakie pojawiają się w jego trakcie. Nie znaczy to jednak, że to ujęcie sprzed blisko stu lat jest nieaktualne. Warszawski psychiatra słusznie podkreśla, że wszystko rozgrywa się tu wokół pytania o sen s symptomów pacjenta, a nie wokół tego, jakie mechanizmy i prawa określają jego psychikę. Interpretacje analityka mogą być trafne lub błędne, nigdy jednak nie można w odniesieniu do nich dostarczyć dowodu za lub przeciw w oparciu o twarde dane empiryczne. Punktem wyj- 
ścia tych rozpoznań i interpretacji jest bowiem wywiedzione z doświadczenia terapeutycznego twórcy nurtu przekonanie, że w psychice pacjentów w nieświadome wypierane są zazwyczaj traumatyczne wydarzenia z przeszłości (oraz, dodajmy, różne, trudne przez niego do zaakceptowania, aspekty relacji $\mathrm{z}$ innymi), których sen su nie jest on w stanie zaakceptować. Nie chce on po prostu nic o nich wiedzieć. A tego typu postawy nie sposób zweryfikować na sposób empiryczny.

We współczesnej, niezwykle obszernej literaturze na temat psychoanalizy Freuda aż roi się od prac filozofów i psychologów, którzy orientując się według modelu naukowości wypracowanego w naukach przyrodniczych (orientacja empiryczno-eksperymentalna), „dowodzą" w nich z niezachwianą pewnością siebie, że praktycznie wszystkie hipotezy i twierdzenia wiedeńczyka nie mają żadnej poznawczej wartości, gdyż nie można ich zweryfikować empirycznie. No i z pasja godną lepszej sprawy wykazują, że w każdym z opisanych przez niego przypadków chorobowych jest wiele wysoce wątpliwych domniemań i interpretacji, które nie mogą zostać naukowo potwierdzone ${ }^{30}$.

$\mathrm{W}$ pewnym sensie maja rację. Problem jednak w tym, że wszystkie te hipotezy i interpretacje dotyczą wspomnianego „hermeneutycznego" wymiaru czy aspektu ludzkiego życia psychicznego, który ze swej istoty nie daje się zobiektywizować i uwiarygodnić empirycznie. Stosowanie wobec niego tego typu naukowych procedur i ich ocenianie w oparciu o obowiązujące w naukach przyrodniczych kryteria jest nieporozumieniem. Owe hipotezy i interpretacje nie odnoszą się bowiem do żadnego anonimowego „mechanizmu” (czy mechanizmów) determinującego psychikę ani do określających ją praw, ale do niepoddającej się ich oddziaływaniom dziedziny sensu. Do

${ }^{30}$ Por. K. Popper, Logika odkrycia naukowego, przeł. J. Kmita, PWN, Warszawa 1977; H.J. Eysenck, Sens $i$ nonsens w psychologii, przeł. M. Brzezińska, PWN, Warszawa 1971; A. Grünbaum, Podstawy psychoanalizy. Krytyka filozoficzna, przeł. E. Olender-Dmowska, Universitas, Kraków 2004. 
tej dziedziny odnoszą się również wszelkiego rodzaju zaburzenia psychiki i będące ich przejawem symptomy. Przybierając zazwyczaj postać językową, wymagają przede wszystkim rozumiejącej interpretacji, a nie podejścia eksperymentalnego, w którym sprowadza się je do statusu quasi-przyrodniczych obiektów i traktuje instrumentalnie.

Podjęty w ten sposób przez analityka wysiłek interpretacyjny, koncentrując się na symptomach pacjenta, odnosi się poprzez nie do jego samorozumienia. To znaczy odnosi się do zaburzeń, jakim ono uległo w wyniku traumatycznych zdarzeń z przeszłości i ukształtowania się określonych relacji zależności od innych. Freud naturalnie popełniał wiele błędów, co wykazywali zresztą później również jego uczniowie i zwolennicy jego teorii. Nie są też wolne od różnego typu pomyłek i błędów i inne wymienione wyżej formy psychoterapii „humanistycznej". Nie chodzi tu jednak o to, aby wygrywać jednego typu formy terapii wobec drugich, argumentując zgodnie z logiką typu „albo - albo”. Tym bardziej że we współczesnej psychiatrii i psychoterapii dominują tendencje do łączenia ze sobą podejść eksperymentalno-empirycznych, w których podkreśla się znaczenie oddziaływania na sferę soma przez leki, z podejściami „humanistycznymi”. W tych drugich z kolei kładzie się nacisk na szereg pozytywnych efektów, jakie można uzyskać poprzez oddziaływanie rozmową na psychikę pacjenta. Te efekty w postaci przeobrażenia samorozumienia pacjenta oddziałują później na jego soma. Dlatego za jednostronne i anachroniczne uznaje się dzisiaj propagowanie koncepcji terapii, w których bierze się pod uwagę tylko jeden typ podejścia ${ }^{31}$.

31 Pionierami podejścia psychosomatycznego w psychoterapii byli często psychoanalitycy z kręgu freudowskiego. Jednym z nich był węgierski psychoanalityk Franz Alexander, który zrobił później karierę w Stanach Zjednoczonych (zob. F. Alexander, The Medical Value of Psychoanalysis, International Universities Press, New York 1984). Drugą znacząca postacią był Georg Groddeck, który zaczynał jako uczeń Freuda (zob. G. Groddeck, Das Buch vom Es, Strömfeld, Leipzig-Wien-Zurich 1923). 
Nie zmienia to jednak w niczym tego, że sposób, w jaki traktuje się ludzką psychikę i jej zaburzenia w „humanistycznych" formach psychoterapii i w psychoanalizie dzieli ontologiczna przepaść $\mathrm{w}$ porównaniu $\mathrm{z}$ formami terapii farmakologicznej i psychochirurgii. Niezależnie bowiem od tego, jak daleko można pójść w łączeniu ze sobą obu tych typów podejść, wszelkiego typu nurty „humanistyczne” w psychoterapii, w tym w szczególności wyrastające na podłożu teorii Freuda współczesne koncepcje psychoanalityczne, zakładają, że zazwyczaj ma się do czynienia z pacjentami, których źródłem zaburzeń psychicznych nie są patologie ciała, zdeterminowane przez czynniki dziedziczne, choroby, uszkodzenia powypadkowe mózgu itp. Źródłem są przede wszystkim zaburzone relacje międzyludzkie, różnego typu konflikty rodzinne, koleżeńskie, zawodowe, partnerskie, oddziałując głęboko na sposób samorozumienia pacjenta. Dlatego podstawowym zadaniem terapeuty jest rozpoznać dobrze te źródła i doprowadzić do tego, że w trakcie terapii pacjent wypracowuje nowe spojrzenie na siebie i własne relacje z innymi. Spojrzenie to ma uwolnić go od różnych, nieuświadamianych przez niego do tej pory, form zależności od innych i od koszmarów przeszłości.

Z późniejszych przedstawicieli nurtu należy wymienić Donalda Winnicotta (zob. Dzieci i ich matki, przeł. M. Halaba, Warszawa 1994), André Greena (zob. Somatisation, psychoanalyse et science du vivant, Eshel, Paris 1994), Joyce McDougall (zob. Teatry ciata. Psychoanalityczne podejście do chorób psychosomatycznych, przeł. M. Kruszyńska-Mąka, Oficyna Ingenium, Warszawa 2014). 


\section{Bibliografia:}

Alexander, Franz, The Medical Value of Psychoanalysis, International Universities Press, New York 1984.

Bachelard, Gaston, La Psychoanalyse du Feu, Les Éditions Gallimard, Paris 1938.

Binswanger, Ludwig, Ausgewählte Vorträge und Aufsätze, t. 1-2, Francke Verlag, Bern 1955.

Bornstein, Maurycy, O odrębnym typie rozszczepienia psychicznego (schizothymia reactiva), Z Oddziału Psychiatrycznego w Szpitalu na Czystem, E. Wende i spółka, Warszawa 1916.

Descartes, René, Namiętności duszy, przeł. Ludwik Chmaj, PWN, Warszawa 1986.

Duch, Włodzisław, Neurobiological Foundations of Ethics and Law (materiały konferencji Ethics in Science and Life pod auspicjami Fundacji Alexandra von Humboldta w Toruniu w maju 2015 roku).

Dybel, Paweł, Dialog i represja. Antynomie psychoanalizy Sigmunda Freuda, Wydawnictwo IFiS PAN, Warszawa 1994.

Eysenck, Hans J., Sens i nonsens $w$ psychologii, przeł. Maria Brzezińska, PWN, Warszawa 1971.

Foucault, Michel, Historia szaleństwa $w$ dobie klasycyzmu, przeł. Helena Kęszycka, PIW, Warszawa 1987.

Gorgiasz, Pochwata Heleny, przeł. Krystyna Tuszyńska, „Przegląd Humanistyczny" 1984, t. 28, nr 3, s. 109-113.

Green, André, Somatisation, psychoanalyse et science du vivant, Eshel, Paris 1994.

Groddeck, Georg, Das Buch vom Es, Strömfeld, Leipzig-Wien-Zürich 1923.

Grünbaum, Adolf, Podstawy psychoanalizy. Krytyka filozoficzna, przeł. Elżbieta Olender-Dmowska, Universitas, Kraków 2004.

Habermas, Jürgen, Erkenntnis und Interesse, Suhrkamp, Frankfurt am Main 1965.

Jekels, Ludwik, Szkic psychoanalizy Freuda, Polskie Towarzystwo Nakładowe, Lwów 1912.

Marcinów, Mira, Psychologiczna charakterystyka chorób umystowych w XIX-wiecznej psychiatrii polskiej, Uniwersytet Jagielloński, Kraków 2014, 480 s. (złożona w wydawnictwie słowo obraz/ terytoria niepublikowana rozprawa doktorska).

Markuszewicz, Roman, A Miraculous Escape. Recollection of a Survival of the Holocaust, przeł. John Hammond, Nakładem tłumacza, Beecroft, Australia 1976 
Markuszewicz, Roman, Psychoanaliza i jej znaczenie lecznicze, „Warszawski Kalendarz Lekarski” 1926, s. 269-338.

McDougall, Joyce, Teatry ciata. Psychoanalityczne podejście do chorób psychosomatycznych, przeł. Marta Kruszyńska-Mąka, Oficyna Ingenium, Warszawa 2014.

Olesiński, Dariusz, Elenktyka jako therapeia $w$ świetle Platońskiego Eutyfrona, w: Therapeia, askesis, meditatio. Praktyczny wymiar filozofii $w$ starożytności $i$ średniowieczu, red. Krzyszof Łapiński, Robert Pawlik, Rafał Tichy, Wydział Filozofii i Socjologii UW, Warszawa 2017, s. 49-59.

Piltz, Jan, Stanowisko psychiatrii w rzędzie innych nauk lekarskich, oraz nowoczesne jej zadania i cele, „Przegląd Lekarski” 1905, nr 30-32, s. 2-15.

Platon, Obrona Sokratesa, przeł. Władysław Witwicki, PWN, Warszawa 2005.

Popper, Karol, Logika odkrycia naukowego, przeł. Jerzy Kmita, PWN, Warszawa 1977.

Ricoeur, Paul, O interpretacji. Esej o Freudzie, przeł. Maciej Falski, Wydawnictwo KR, Warszawa 2008.

Shorter, Edward, A History of Psychiatry. From the Era of the Asylum to the Era of Prozac, John Wiley \& Sons, New York 1977.

Trillat, Etienne, Historia histerii, przeł. Zofia Podgórska-Klawe, Elżbieta Jamrozik, Ossolineum, Wrocław-Warszawa-Kraków 1993.

Winnicott, Donald, Dzieci i ich matki, przeł. Małgorzata Halaba, W.A.B., Warszawa 1987.

Prof. dr hab. Paweł Dybel

Instytut Filozofii i Socjologii

Uniwersytet Pedagogiczny w Krakowie pawedybel@gmail.com 